\title{
Recent expansion of the slipper limpet population (Crepidula fornicata) in the Bay of Mont-Saint-Michel (Western Channel, France)
}

\author{
Michel Blanchard ${ }^{\mathrm{a}}$ \\ IFREMER, Dép. Dynamiques de l’Environnement Côtier (DYNECO), BP 70, 29280 Plouzané, France
}

Received 6 October 2008; Accepted 14 January 2009

\begin{abstract}
A population of the invasive slipper limpet (Crepidula fornicata) has been spreading in the Bay of MontSaint-Michel (Western English Channel) for 40 years. Sidescan sonar, underwater video and quantitative sampling were conducted in 1996 and 2004 to document the widening geographic spread of the species over the bay. The limpet population grew by 50\% during this period, to reach a fresh biomass of about $150000 \mathrm{t}$. This local study analyses causes and effects of the spread and provides a typical example of the limpet spreading process. This population increase has significant effects on the environment in the most densely colonized area (modification to the sediment and biodiversity), leading to the emergence of a new benthic community. Anthropic dredging activities are among the causative factors of the spread but are also adversely affected by the invasion.
\end{abstract}

Key words: Invasive species / Spread / Oyster-farming / Stock estimation / Sidescan sonar / Crepidula fornicata / Western Channel, France

\begin{abstract}
Résumé - Récent bilan de la prolifération de la crépidule (Crepidula fornicata) en baie du Mont Saint-Michel (Manche Ouest). Depuis 40 ans, la population de crépidules (Crepidula fornicata) prolifère en baie du Mont SaintMichel (Manche Ouest). Deux études réalisées en 1996 et 2004 ont permis de cartographier et d'estimer le stock de la population grâce à des moyens similaires : sonar à balayage latéral, vidéo sous-marine et prélèvements quantitatifs à la benne. Durant cet intervalle de temps, la biomasse a augmenté de $50 \%$ pour atteindre 150000 t dans la baie en 2004. Cette étude comparative a permis d'analyser les causes et les effets d'une telle prolifération et d'en montrer le processus général. Dans les secteurs fortement colonisés, les effets sur l'environnement sont particulièrement néfastes (modification du sédiment et de la biodiversité) et aboutissent à une nouvelle communauté benthique. Les activités de pêche aux engins traînants (dragues et chaluts) sont à la fois les principales responsables et les victimes de cette prolifération.
\end{abstract}

\section{Introduction}

During the last hundred years, a host of marine species have been introduced into European waters, either accidentally or by intent, due to increasing in international trade (Carlton and Geller 1993; Reise et al. 1999; Leppäkoski et al. 2002; Panov and Gollasch 2004; Reise et al. 2006). For example, 108 new species have been observed in the waters around mainland France over the last hundred years (Goulletquer et al. 2002). Among these is the slipper limpet, Crepidula fornicata (L. 1758), a native of the Atlantic coast of North America, whose biological characteristics have been a subject of study for many years (Walne 1951). This small gastropod was first introduced accidentally into England (McMillan 1938), then into several European countries, especially in France, during

\footnotetext{
a Corresponding author: Michel.Blanchard@i fremer.fr
}

the 1930s, because of the emerging trade of the native flat oyster, Ostrea edulis L. 1758. The slipper limpet was again accidentally re-introduced into all European shellfish growing areas during the 1970s with a massive importation of Pacific oysters, Crassostrea gigas (Thunberg 1793), brought in to relaunch oyster-farming (Blanchard 1995, 1997; Wolff and Reise 2002). Following its introduction, the species acclimated so well that it spread to all bays and estuaries, from Norway to Spain. The English Channel, where the limpet was first observed during the 1930s (Holme 1961), is today at the centre of its European distribution area and has the highest concentrations. The species is observed along English and French coasts, from the lower ebb tide level to the deepest grounds, and from the Atlantic Ocean border to the Dover Strait and the North Sea (de Kergariou et al. 1979; Utting and Spencer 1992; Arenas et al. 2006). 


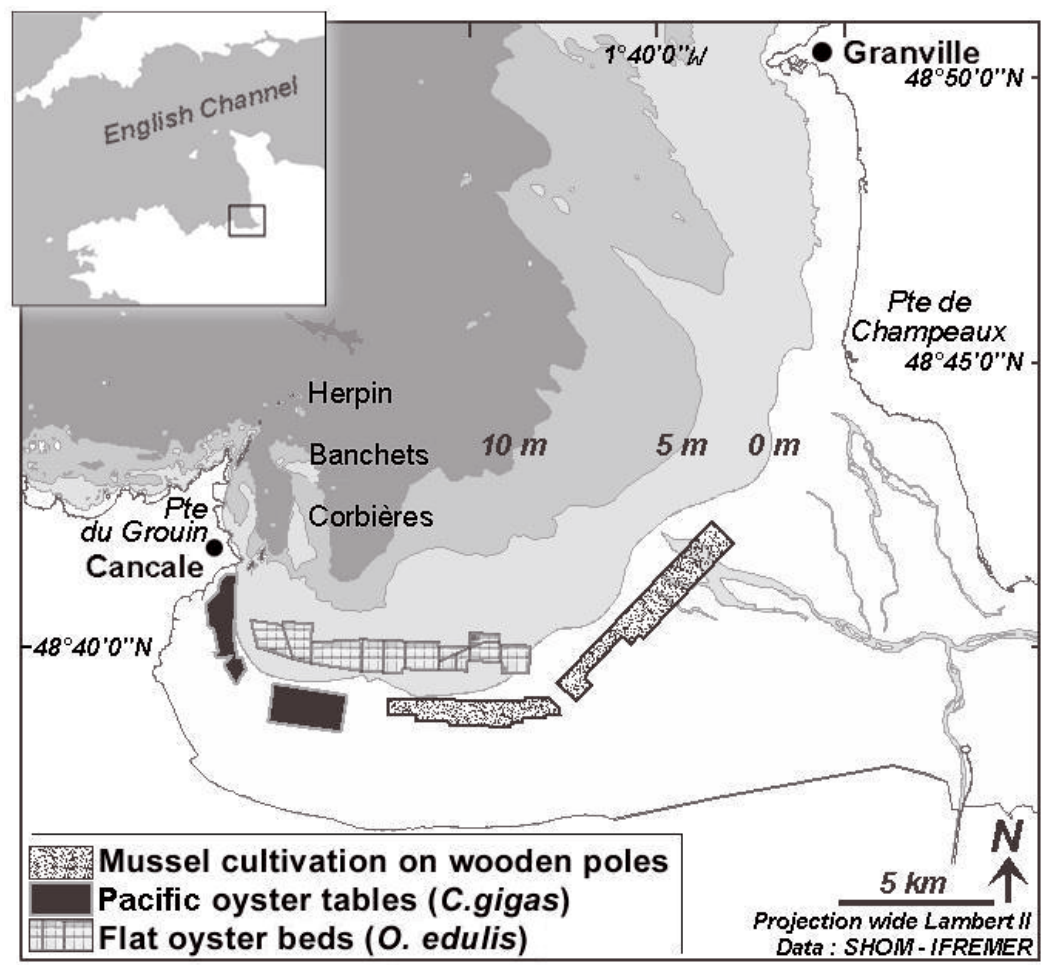

Fig. 1. Map of the Bay of Mont-Saint-Michel and its shellfish-farming zones.

In the south of the Norman gulf (Western Channel), the Bay of Mont Saint-Michel is highly colonized. This bay covers $240 \mathrm{~km}^{2}$ of intertidal and $135 \mathrm{~km}^{2}$ of subtidal areas, between the Pointe du Grouin and the Pointe de Champeau (Fig. 1). The eastern part of the bay is a delta for three rivers (the Sée, the Sélune and the Couesnon), mainly intertidal and under the influence of a strong tidal flow (Marchand et al. 1998). The western part of the bay, also called the Bay of Cancale, is a wide shallow sandy area protected from westward swells by the Herpin islands, which thus provides a sheltered area for shellfish farming. This bay produces $5000 \mathrm{t} \mathrm{y}^{-1}$ of Pacific oysters (Crassostrea gigas) and $10000 \mathrm{t}$ of common mussels, Mytilus edulis L. 1758, on the shore. Subtidal culture of flat oysters (Ostrea edulis) produces $1500 \mathrm{t} \mathrm{y}^{-1}$ (50\% of French national production) on 880 ha of underwater beds in the centre of the bay (Mazurié and Bouget 2003). This latter activity is directly impacted by the slipper limpet, which not only spreads rapidly into the oyster beds and their surroundings but also becomes attached to the oyster shells.

The rapid dispersion and biomass increase of the slipper limpet causes a host of negative ecological impacts in the bay, such as ground covering, increase in suspension-matter filtration, mud deposition and changes in benthic biodiversity. Furthermore, an economic impact is felt when cleaning operations are necessary on shellfish rearing areas (Blanchard 1997). Spatial competition has developed between cultivated oysters and slipper limpets but, in contrast to other sites like Arcachon Bay (Montaudouin et al. 1999) or Bourgneuf Bay (Decottignies et al. 2006, 2007) where these species co-exist, no trophic competition is observed in the Bay of Mont-St-Michel (Riera 2007).
A survey of this invasive species was thus necessary, not only because of the threat to shellfish production but also because the bay is a world famous site: it has a universally known listed monument, is a landscape heritage site protected since 1979 by UNESCO (the United Nations for Educational, Scientific and Cultural Organization), and is also a listed environment protected for its wetlands by the International Convention of Ramsar (1971) and by the European nature conservation network "NATURA 2000". Many studies have therefore been carried out in this bay, but the first complete mapping and stock estimation of the limpet population was done in 1996 (Blanchard and Ehrhold 1999). Today, thanks to the PNEC (National Program on Coastal Environment) program, which has created an ecological model of trophic fluxes in the bay (Cugier et al. pres. comm.), a new limpet population survey and cartography study was undertaken in 2003-2004. This new survey offers the possibility to make a comparison with the previous results, published 8 years earlier. The present paper makes a comparative study of the results of the two surveys and comments on limpet expansion in this particular bay. It also gives a more general description of the typical invasion process of this species, which can be seen in other regions.

\section{Materials and methods}

Two series of research cruises were made, the first in May and July 1996, the second in May 2003 and May 2004, either on the R.V. "Thalia", or on the oyster boat "Notre-Dame". The same methods were applied for mapping operations on both 
Table 1. Technical characteristics of each series of cruises.

\begin{tabular}{lcc}
\hline Research cruises & $\mathbf{1 9 9 6}$ & $\mathbf{2 0 0 3 - 2 0 0 4}$ \\
\hline Length (days) & 11 & 20 \\
Sonar characteristics & Dowty 3050 & Edgetech DF1000 \\
Sonar profiles length $(\mathrm{km})$ & 30 & 85 \\
Number of video profiles & 20 & 24 \\
Number of grab sampling & 68 & 63 \\
stations & & \\
Surface analysed $\left(\mathrm{km}^{2}\right)$ & 121 & 128 \\
\hline
\end{tabular}

surveys using sidescan sonar, underwater video and quantitative sampling (Table 1).

Sidescan sonar was used to efficiently map the subtidal part of the bay. This technique was developed in our laboratory to describe the limpet population in the Bay of SaintBrieuc (in Blanchard 1995) and has since been used in other bays (Sauriau et al. 2002). This type of sonar is more generally used in geological studies to observe and characterize the morphology and nature of the seabed, but is now being used increasingly to describe the benthic habitats of marine fauna (Kenny et al. 2003; Allen et al. 2005; Ehrhold et al. 2006). In digital sidescan sonar imagery, high backscatter is generally represented by dark tones and low backscatter by light tones; areas of high backscatter are associated with relatively coarser-grained sediments and hard calcareous shells, and areas of low-backscatter with relatively finer-grained sediments. The reflectance of hard shells is used to distinguish mollusc populations on a sandy or muddy bottom, and groups of colonies are thus easily observed. When there is a high density, the limpet population reflects the acoustic wave in a similar way to a mussel bioherm (Wildish et al. 1998). The higher the density, the stronger the reflection. The configuration yielded a theoretical along-track resolution of $\sim 15 \mathrm{~cm}$. The towfish with the transceiver (EdgeTech DF1000 or Dowty 3050) was towed behind the ship at 4 knots. The position was determined as an offset of the vessel DGPS (differential global positioning system), with an accuracy $\pm 5 \mathrm{~m}$, registered and geo-referenced. Data were digitized in the towfish and transmitted via the tow cable to the topside acquisition system. Hard copies of the $100 \mathrm{kHz}$ sonograms were printed on thermal film during acquisition using an EPC HSP-100 thermal plotter. With this technique, about $2 \mathrm{~km} \mathrm{~h}^{-1}$ could be covered with joined profiles that were generally $200 \mathrm{~m}$ wide (100 m to each side of the vessel). Information supplied by oyster farmers together with our own previous observations were used to guide our research cruises. When the limpets were rare or absent (absence supposed or observed), gaps were left between the profiles and results were interpolated.

Direct underwater observation was used to validate the acoustic results whenever necessary. Short $10-15$ min video drags were conducted at several locations in the bay. To achieve this, a camera was fixed on a small sleigh, drawn slowly and geo-referenced with Videonav ${ }^{\circledR}$ software. The limpet patch positions and their densities were compared with the sidescan sonar results.

The recording of the vessel course was processed with Caraïbes ${ }^{\circledR}$ software (developed by Ifremer) and used to draw out a map on paper at 1:10 000 scale, georeferenced by the
WGS 84 datum (World Geodetic System 1984). A time mark was inserted every minute along the recorded vessel course and noted every minute on the sonograms. Grey tonalities were read visually on the paper sonograms and translated into covering rates using a reference chart based on previous experience. These rates were then reported on the map in the corresponding position. Direct observations from video and grab samples were used to validate this information. Maps were assembled and covering rates were finally combined into five levels (Fig. 2): level 1: no limpets could be observed by sonar, level 2: limpets covered between 1 and $20 \%$ of the surface, level 3: between 21 and 50\%, level 4: between 51 and $70 \%$ and level 5: between 71 and $100 \%$. When this last value was observed, the live population covered the sediment completely like a uniform carpet (Fig. 2), which was about 10-15 cm thick and could cover a hundred square metres. The sediment characteristics were also noted during the observations by sonar, video or on the grab samples. Data were compared with published results (Vaslet et al. 1978; Ehrhold 1999) that broadly show sandy grounds in most areas, with muddier sediment in the south-western part of the bay and coarser sediment in the eastern part. Maps were drawn using ArcGis 9.3 ${ }^{\circledR}$ software.

Quantitative evaluation with a grab sampler was undertaken after the cartographical work was completed. Following sonar and video observations, iso-concentrated areas were demarcated so that grab sampling stations could be selected for validation, sediment samples and density / biomass measurements. The number of grab stations was related to the surface area of each level of covering rate. Outside the area covered by the sonar surveys, other grab stations were sampled to complete information for the whole bay. Three samples $\left(0.25 \mathrm{~m}^{2}\right.$ each) were obtained at each station using a Hamon grab or by diving. The samples were sieved on a $2 \mathrm{~mm}$ mesh and animals were frozen. In the laboratory, the limpets were brushed to remove epibionts, cleaned, drained and weighed. The biomass for a station was estimated by the mean value of the three samples (total fresh weight) converted to a mean value per square metre with its standard deviation. Within each level of covering rate, the biomass was calculated as the product of the mean station biomass per unit area and the surface area. The variation around the final result was weighted by the number of stations in each level (Frontier 1983).

\section{Results}

In $1996,121 \mathrm{~km}^{2}$ were analysed in the south-western part of the Bay of Mont-Saint-Michel (Fig. 3). The limpet population was especially concentrated in the south of this area, near the flat oyster beds, between 0 and $5 \mathrm{~m}$ depth. In the other parts of the bay, the limpets were rare or poorly distributed, with only single limpets generally being observed, and the ground cover never exceeding $20 \%$. The densest population $(71-100 \%)$ covered $4.15 \mathrm{~km}^{2}$. Away from this centre, the concentrations decreased regularly. This population was drawn along the shore by a residual current running from east to west (Garreau 1993) which then headed northwards between the coast and the Corbières sandbank. The sandy areas (Corbières bank and Banchet banks) were not colonized because of 

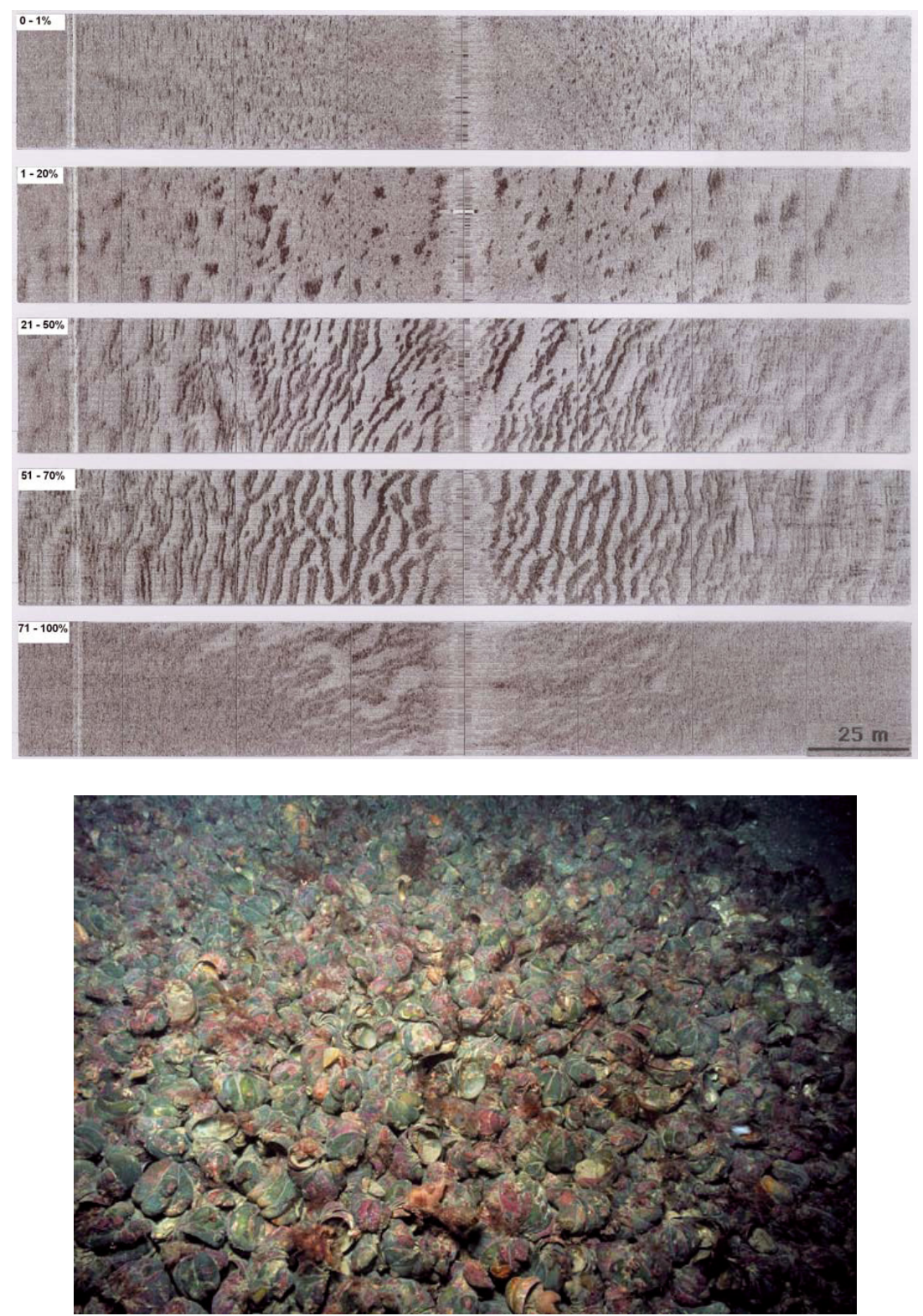

Fig. 2. Top: examples of sonograms showing several limpet covering rate levels (from 1, 20, 50, 70 to 100\%). Bottom: Photograph (Ifremer) of a seafloor completely covered by the slipper limpet population.

surface sand mobility, but many $C$. fornicata chains were observed next to them. Indentations were observed on the northern border of the $21-50 \%$ area of the dense population, due to coarse sand (Augris et al. 2008) that larvae can attach themselves to more easily. An isolated area of the highest density level occurred in front of the mussel farms. Only individuals were observed on the shore, especially in the Cancale oyster beds.

In 2004, most of the subtidal area was mapped by sidescan sonar (Fig. 3). Eighty five percent of this analysed area was colonized by the limpet, from 0 to $15 \mathrm{~m}$ depth. The lowest densities were in the northern and eastern parts of the bay, where only scattered individuals were observed. The highest densities (71-100\%) were only found along the flat oyster beds, but covered an area of $14 \mathrm{~km}^{2}$ : three times the area occupied 8 years before. This highest density reef of $C$. fornicata extended to the north following the indentations already observed due to coarse sands. Overall, iso-density levels were not as regular as in 1996 and extensions could be seen in several directions. In the western area, off Cancale, the limpet patch was wider and reached the lower shores but densities were lower than before (possibly due to effects of dredging). In this bathymetric depression, the animals were regularly pushed by the current. To the south of the Herpin islands, the sand banks were not colonized, because the current passing between the islands is strong enough to push two thirds of the larvae out of the bay during the ebb tide (Cugier pers. comm.). In the south-east of the bay, a dense patch has developed where limpets have invaded an area inside a new mussel farm on the shore. Another patch has developed in the East, on coarse sand. 


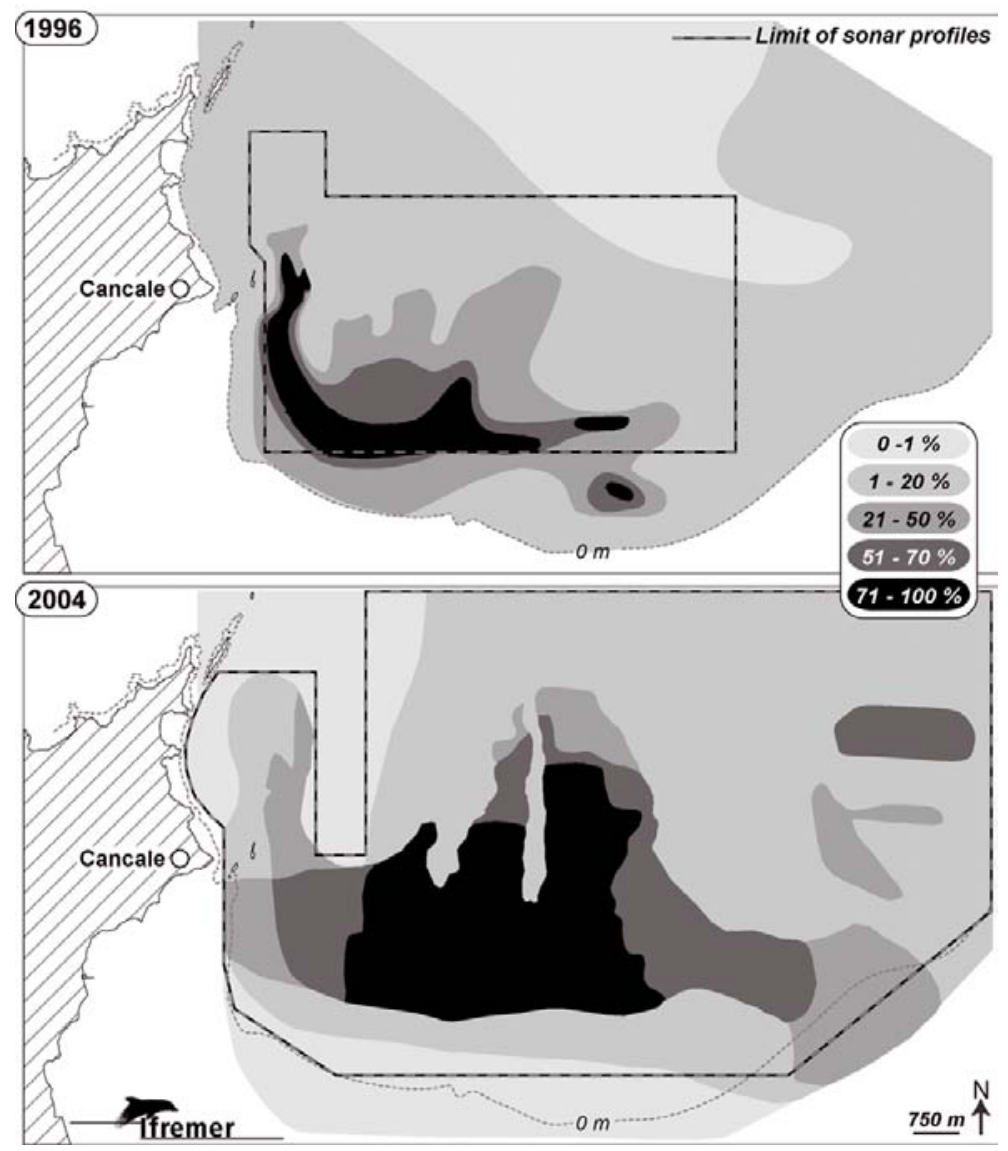

Fig. 3. Studied areas and limpet population covering rate levels, in 1996 (above) and in 2004 (below).

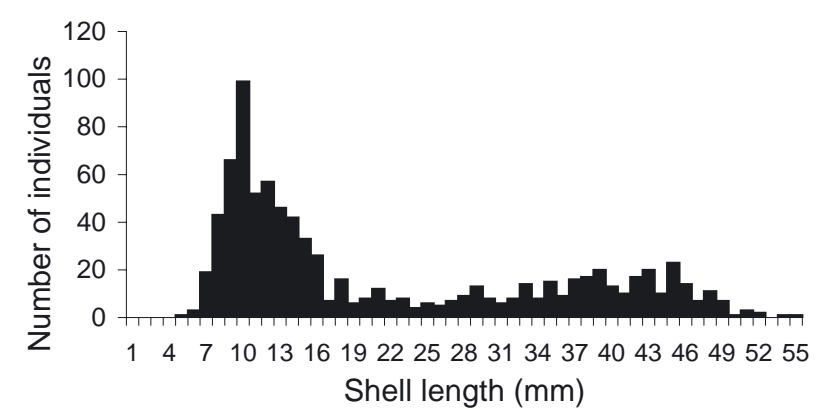

Fig. 4. Shell length in a slipper limpet sample, measured in May 2004 in the southern part of the bay.

Length measurements were made on limpets in 2003 and 2004 for population dynamics studies. It appeared that the recruitment rate was generally high; the first cohort represented $58 \%$ of the sample (Fig. 4).

The fresh biomass measured in 1996 was estimated to be 107475 metric tons; the variation calculated following Frontier (1983) was $\pm 19205 \mathrm{t}$. About a quarter of the biomass $(28080 \mathrm{t}, \mathrm{SD}=32727 \mathrm{t})$ was concentrated inside the $4.15 \mathrm{~km}^{2}$ area of maximum density, but about $48000 \mathrm{t}(\mathrm{SD}=59317)$ were in the areas with lower density levels $(\leqslant 20 \%$ ground coverage) covering three quarters of the bottom surface. In 2004, $128 \mathrm{~km}^{2}$ were mapped and 63 grab samples produced an estimated fresh biomass of $149904 \mathrm{t}($ variation $=17038 \mathrm{t})$. The slipper limpets were highly aggregated with about half of the fresh biomass (77568 t \pm 47508$)$ occurring in a dense cluster $\left(\geqslant 71 \%\right.$ seafloor coverage) over only $14 \mathrm{~km}^{2}$. In this area, several samples contained over $10 \mathrm{~kg} \mathrm{~m}^{-2}$. The biomass of each covering rate is compared in Figure 5, which highlights this increase in higher density levels between the surveys. The lowest covering level of $0-1 \%$, representing $38 \%$ of the bay in 1996, occupied only $13 \%$ in 2004 . The highest densities (covering $51-100 \%$ of the bottom) occupied a surface of $7 \mathrm{~km}^{2}$ in 1996 with a $37000 \mathrm{t}$ biomass. In 2004, however, $25 \mathrm{~km}^{2}$ was covered to these density levels and contained $110000 \mathrm{t}$. The quantity of limpets was therefore about three times higher in 2004 compared with 1996, in terms of both area and biomass.

The dead shells in the lower part of the stacks (not included in the biomass) represented about $28 \%$ of their fresh weight, thus representing about $42000 \mathrm{t}$ for the whole bay. Following previous laboratory results on biodeposition rates (in Ehrhold et al. 1998), the biodeposits of this population could be estimated at about $771 \mathrm{t} \mathrm{h}^{-1}$ of fresh matter, $25 \%$ of which was organic (mucus and non digested matter); according to this estimation the limpet population is thus depositing $6.7 \times 10^{6} \mathrm{t}^{-1}$ in the bay.

The dispersion process observed by sidescan sonar showed that the first animals settle in depressions like ripple-marks or sand wave hollows. These isolated colonies expand into linear forms (Fig. 2), which become increasingly wider until 


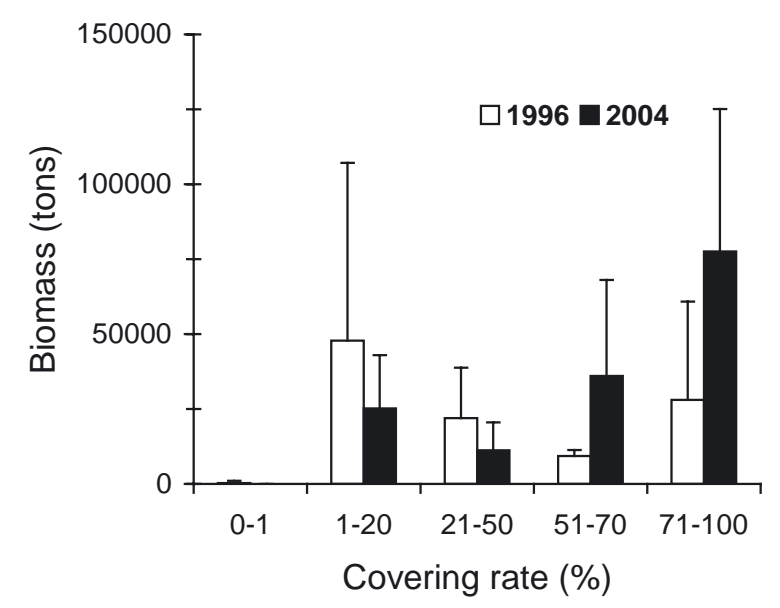

Fig. 5. Slipper limpet biomass for each covering rate level, for both survey periods (means and standard deviations).

the entire depression is completely covered. The remnants of the linear shape can be seen as indentations along the colony edge, which we found to be a good means of identifying mature slipper limpet communities. The population extends spatially in steps and thickens. The ground level rises slightly because of the accumulation of dead shells and biodeposits, which progressively incorporate the lower layer and fundamentally change the physical and chemical composition of the sediment (Ehrhold et al. 1998). When the sediment is completely covered and no longer oxygenated, it becomes putrid, black and unsuitable for endofauna, which then disappear. Sediment analysis showed that this profound change starts to become definitive and irreversible above a $50 \%$ covering rate. The biodiversity then changes: the fine-sand community disappears, the dense limpet population becomes like a reef, fixed suspension-feeders settle (ascidians, tubicolous worms, fixed shellfish, etc.) and a vagile carnivorous microfauna invades the empty shells and interstices. A homogeneous slipper limpet community has then become a permanent seafloor feature covering the whole area.

\section{Discussion}

The slipper limpet appeared in the Bay of Mont-SaintMichel at the beginning of the 1970s following the introduction of Pacific oysters from the French Atlantic coast, which was already infested (Blanchard and Ehrhold 1999). The population initially settled in the muddy intertidal beds of Cancale and then rapidly shifted towards the neighbouring sublittoral sandy beds where flat oyster cultivation had just begun, providing abundant shell substrates for larval settlement. Observations made in 1975 showed a large number of juveniles, indicating rapid population expansion near Cancale. The species was subsequently seen in other parts of the bay. A biomass of about $20000 \mathrm{t}$ (unpublished data) was estimated in 1980 based on interviews with oyster farmers and our own measurements. The 2004 survey demonstrated that there had been a $50 \%$ increase in the slipper limpet biomass in the 8 years since the 1996 survey, corresponding to an increase of approximately $9000 \mathrm{t} \mathrm{y}^{-1}$ (Fig. 6). Such a rapid biomass increase has

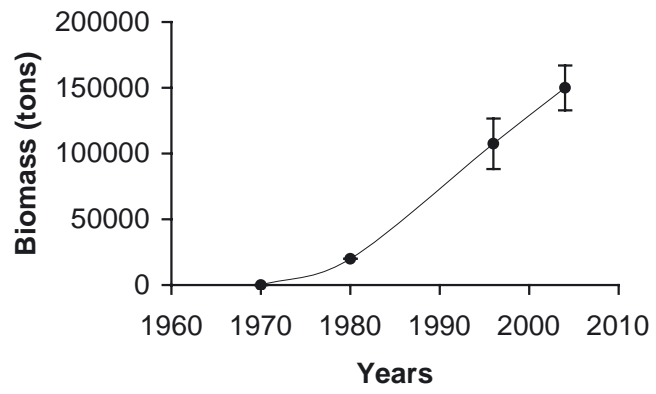

Fig. 6. Biomass expansion of the slipper limpet population in the Bay of Mont-Saint-Michel.

never been reported anywhere else for a marine species. Continued expansion is unfortunately to be expected for several years because there are no signs of levelling off that could indicate stabilization in the expansion rate. Today, 40 years after its introduction, the species is still in a spectacular expansion phase. The expansion is illustrated by the high juvenile densities measured in May 2004 in the population centre (Fig. 4), where the first cohort represented $58 \%$ of the population. This species is now the most prevalent in the bay, making up 51\% of the benthic biomass (Arbach-Leloup et al. 2008).

The sidescan sonar surveys were effective at distinguishing the slipper limpet populations from sandy seafloor features and allowed us to make a detailed comparison between 1996 and 2004 surveys. This method is highly recommended for surveys of this kind, particularly as automatic recorders and new softwares are now available. All the cartographic data were analyzed with the GIS (Geographic Information System) ArcMap software which was set up in the bay for the PNEC program. The sedimentary information has contributed to the recent publication of a superficial sediment map of the bay (Augris et al. 2008).

The slipper limpet has several biological characteristics that aid rapid population development: colony formation, hermaphroditism, long egg-laying period, pelagic larvae and resistance to environmental variations (Le Gall 1980; Richard et al. 2006). The population dynamics study showed massive recruitment in the bay and an annual turnover of $29.6 \%$ in dense areas. Furthermore, several local parameters favour its spread in the Bay of Mont-Saint-Michel.

The main reason for the presence and expansion of this species in the bay is the practice of oyster farming, especially flat oyster farming on underwater beds. This culture, which is done at about $5 \mathrm{~m}$ depth and uses only dredges, seems to favour limpet development. Firstly, the flat oysters provide a suitable calcareous living substrate for the limpet larvae; their density can exceed $10 \mathrm{~m}^{-2}$ and numerous dead oyster shells are also present. Secondly, the limpet population can develop undisturbed for two years while the oysters are left to grow. Indeed, after the oyster seed have been spread few activities take place until harvest, so the limpets can develop unheeded. It is only when the two-year-old oysters are ready to be sold and are dredged that the limpets are removed. Thirdly, up until recently, the limpets were generally thrown overboard, thus favouring their dispersion. Furthermore, when the oyster seed is imported and laid in summer, some oyster farmers 
put out mussel shells to improve fixation; as the limpet larvae are present during this period, they can also settle onto these mussel shells. These shellfish farming practices have to some extent nurtured the invasive species for several decades, and are considered simultaneously to be among the causes and the victims of the limpet spread.

The second reason for the spread is the constant dredging and trawling (for fish, shellfish and cuttlefish) that have been going on for several decades in the bay. The trawlers pass along the oyster beds picking up limpets on the way, which are then sorted and thrown overboard in another part of the bay. This activity has increased the natural dispersal of adult slipper limpets. A comparative study, carried out in several bays along the French coasts, has highlighted the responsibility of such dredging and trawling activities in limpet dispersion and spread outside the shellfish beds. The heavy dredges cut and divide the limpet chains; they also crush the shells, generating areas of suitable colonization substrate, and create furrows in the bottom where the limpets settle. It appears clear that trawling and dredging activities help to spread the slipper limpet population.

The third reason for such dispersion is the particular nature of water circulation in the Bay of Cancale, which is protected from the main swells coming from the western English Channel. Here, a residual circular flow turns clockwise, passing over the limpet population centre (Garreau 1993). A part of the flow goes northwards to the Herpin islands and another part heads towards the south-east before returning back towards the deeper part of the bay. Cugier (pers. comm.) estimates that during July, when larval densities are highest (Quiniou and Blanchard 1987), even though most larvae leave the bay through the islands, $10 \%$ are still present within the bay after 33 days, which is the duration of their pelagic life at summer temperature of $18-20{ }^{\circ} \mathrm{C}$ (Pechenik 1984). This natural dispersal can carry the larvae throughout the Bay of Cancale. In contrast, the eastern part of the bay is deltaic, exposed to the swells and to a strong alternating tidal flow (Marchand et al. 1998), preventing larval settlement.

Some local environmental parameters also promote limpet population development: an optimal temperature range (5$20{ }^{\circ} \mathrm{C}$ ), high phytoplankton diversity and concentrations (mean chlorophyll $2.5 \mu \mathrm{g} \mathrm{L}^{-1}$ ), shallowness $(0-20 \mathrm{~m}$ ) and low salinity $\left(20-35 \%\right.$ ). The larvae are active above $15{ }^{\circ} \mathrm{C}$ (Pechenik 1984) and this temperature is found in the bay between April and October, although the egg-laying period can be longer and the number of layings can increase if optimal temperatures last longer, as in 2003 for example (Richard et al. 2006). Hiscock et al. (2004) showed that water temperature in the Channel rose by $1{ }^{\circ} \mathrm{C}$ between 1990 and 2000, which could partly explain the local limpet expansion over recent years in this and other bays of the Channel or North Sea (Thieltges et al. 2004; Nehls et al. 2006).

No specific shellfish predators have been observed. Predation by carnivorous fishes present in the bay, such as sea bass (Kelley 1987; Feunten and Lafaille 1997), has not been evaluated but seems relatively weak, as is the case of the predation by the numerous diving waterbirds. Larvae predation by adult oysters and limpets has been measured (Pechenik et al. 2004) but demonstrated to have only a weak effect on the total limpet population.

During the 8-year study period the limpet population spread to cover all subtidal parts of the bay, but the spatial capacity of the grounds has not yet reached saturation levels. Our results show that the spread is progressing eastwards with higher densities and in the centre of the bay where the covering rate is also increasing. The species has reached both deep and shallow areas and now partly covers the lower intertidal areas (especially in front of the mussel beds). Today, $25 \%$ of the bay is covered at the highest density levels (51$100 \%$ ) and other areas could subsequently become more heavily populated. Outside the bay, many observations and measurements have been made over recent years, which confirm the rapid increase in densities in the Norman gulf. Viard et al. (2006), using genetic measurements associated with a physical model, demonstrated that larvae originating from the Bay of Mont-Saint-Michel have colonized areas up to Jersey; the bay thus appears to be a main population centre for the gulf. Compared with other neighbouring bays in northern Brittany that also have very large limpet populations, the Bay of MontSaint-Michel has the highest limpet concentrations. The Bay of Mont-Saint-Michel has a limpet density of $11.6 \mathrm{t} \mathrm{ha}^{-1}$, while the Bay of Brest has $8.20 \mathrm{tha}^{-1}$ (Guérin 2004) and the Bay of Saint-Brieuc has $2.88 \mathrm{t} \mathrm{ha}^{-1}$.

Today it is too late to envisage eradication of the limpets from Mont-Saint-Michel Bay. To fight against this species and to limit the negative effects, the only efficient method is to carry out regular collection using light dredges, provided that the entire dredge contents are landed ashore including live limpets and a maximum amount of dead shells. Before serious modifications occur in the sediment when the ground is extensively covered, and to prevent this from happening, it would be better to dredge the lightly colonized areas in addition to the highest density reefs. An industrial sucker dredge was tested from 2001 to 2005 in the population centre and the product, dried and treated, was used as a calcareous supplement for agriculture. Thirty thousand tons of live limpets were extracted meaning that $6000 \mathrm{t}$ were collected per year. This level of removal was not enough to offset the theoretical rise of $9000 \mathrm{t} \mathrm{y}^{-1}$ in this population centre. Without this operation, however, the biomass in the bay would have been about $174000 \mathrm{t}$ in 2004. Several value-adding practices have been tested for the dredged product. Other ideas, especially the use of this edible shellfish in cooking, await further promotion in the bay. Such initiatives to encourage large scale harvesting are vitally important as, if environmental conditions and anthropic processes remain at the same level, the limpet population will continue to grow at a high rate and cause even greater economic and environmental impacts.

\section{Conclusion}

The slipper limpet has long been studied for its biological characteristics (reproduction and behaviour), but is now being studied more particularly for its effects on the environment. Among the effects observed in the Bay of Mont-Saint-Michel, the modification to the sediment seems to be the most damaging (Ehrhold et al. 1998): a cohesive anoxic mud is formed, 
making it definitively unsuitable for other species. By 2004, $25 \mathrm{~km}^{2}$ of the bay had already become unsuitable. We estimated a theoretical biodeposition rate of more than $6.0 \times 10^{6}$ fresh tons a year, increasing the natural suspension-matter deposition rate which is estimated to be $1.5 \times 10^{6} \mathrm{t}^{-1}$ in this area (Ehrhold 1999), so that the situation will worsen. The first results of the PNEC program have not revealed, up to now, any noticeable effects of slipper limpet feeding behaviour on other suspension-feeder populations (Riera 2007; Cugier et al. pres. comm.), even the cultivated ones (Mazurié pers. comm.), but new results could reveal other processes. To deepen our understanding and prevent harmful effects on shellfisheries it would be useful to conduct new surveys on environmental parameters and on the limpet population itself in coming decades.

Acknowledgements. The author sincerely thanks the crews of both ships and the Ifremer technicians who operated the sidescan sonar, P. Clabaut and E. Houlgatte for sonogram examinations and anonymous reviewers for their comments. This work was funded by the PNEC program (National Program of Coastal Environment).

\section{References}

Allen Y.C., Wilson C.A., Roberts H.H., Supan J., 2005, High resolution mapping classification of oyster habitats in nearshore Louisiana using sidescan sonar. Estuaries 28, 435-446.

Arenas F., Bishop J.D.D., Carlton J.T., Dyrynda P.J., Farnham W.F., Gonzalez D.J., Jacobs M.W., Lambert C., Lambert G., Nielsen S.E., Pederson J.A., Porter J.S., Ward S., Wood C.A., 2006, Alien species and other notable records from a rapid assessment survey of marinas on the south coast of England. J. Mar. Biol. Assoc. UK 86, 1329-1337.

Arbach-Leloup F., Desroy N., Le Mao P., Pauly D., Le Pape O., 2008, Interractions between a natural food web, shellfish farming and exotic species; case of the Bay of the Mont Saint Michel. Estuar. Coast. Shelf Sci. 76, 111-120.

Augris C., Bonnot-Courtois C., Ehrhold A., Mazé J.P., Le Vot M., Blanchard M., Simplet L., 2008, Carte des formations superficielles du domaine marin côtier de Saint-Malo à Granville, 1/50 000 ${ }^{\mathrm{e}}$, IFREMER-CNRS-EPHE, Quae editions.

Blanchard M., 1995, Origine et état de la population de crépidule (Crepidula fornicata) sur le littoral français. Haliotis 24, 75-86.

Blanchard M., 1997, Spread of the slipper-limpet (Crepidula fornicata) in Europe. Current state and consequences. Scient. Mar. 61, 109-118.

Blanchard M., Ehrhold A., 1999, Cartographie et évaluation du stock de crépidules (Crepidula fornicata) en baie du Mont SaintMichel. Haliotis 28, 11-20.

Carlton J.T., Geller J., 1993, The ecological roulette; the global transport and invasion of non-indigenous marine organisms. Science 261, 78-82.

Decottignies P., Beninger P., Rince Y., Riera P., 2006, Trophic interactions, between two introduced suspension feeders Crepidula fornicata and Crassostrea gigas, are influenced by seasonal effects and qualitative selection capacity. J. Exp. Mar. Biol. Ecol. 342, 231-241.

Decottignies P., Beninger P., Rincé Y., Robins R., Riera P., 2007, Exploitation of natural food sources by two sympatric invasive suspension feeders Crassostrea gigas and Crepidula fornicata. Mar. Ecol. Prog. Ser. 334, 179-192.
Ehrhold A., 1999, Dynamique de comblement d'un bassin sédimentaire soumis à un régime mégatidal : exemple de la baie du Mont Saint-Michel. Thèse Univ. Caen.

Ehrhold A., Blanchard M., Auffret J.P., Garlan T., 1998, Conséquences de la prolifération de la crépidule (Crepidula fornicata) sur l'évolution sédimentaire de la baie du Mont SaintMichel (Manche, France). C.R. Acad. Sci., Paris 327, 583-587.

Ehrhold A., Hamon D., Guillaumont B., 2006, The REBENT monitoring network, a spatially integrated, acoustic approach to surveying nearshore macrobenthic habitats: application to the Bay of Concarneau (South Brittany, France). ICES J. Mar. Sci. 63, 1604-1615.

Feunten E., Lafaille P., 1997, Les peuplements piscicoles de la baie du Mont Saint-Michel. Penn Ar Bed 164, 50-56.

Frontier S., 1983, Stratégies d'échantillonnage en écologie. Collection d'écologie vol. 17. Presse Universitaire de France, Masson, Paris.

Goulletquer P., Bachelet G., Sauriau P.G., Noel P., 2002, Open Atlantic coast of Europe; A century of introduced species into French waters. In: Invasive Aquatic Species of Europe ; distribution, impacts and management. Leppäkoski E., Gollasch S., Olenin S. (Eds.) Kluwer, Dordrecht, pp. 276-290.

Garreau P., 1993, Hydrodynamics of the north Brittany coast; a synoptic study. Oceanol. Acta 16, 469-477.

Guérin L., 2004, La crépidule en rade de Brest; un modèle d'espèce introduite proliférante, en réponse aux fluctuations de l'environnement. Thèse UBO Brest.

Hiscock K., Southward A., Tittley I., Hawkins S., 2004, Effects of changing temperature on benthic marine life in Britain and Ireland. Aquat. Conserv. Mar. Freshw. Ecosyst. 14, 333-362.

Holme N.A., 1961, The bottom fauna of the English Channel. J. Mar. Biol. Assoc. UK 41, 397-461.

Kelley D.F., 1987, Food of bass in UK waters. J. Mar. Biol. Assoc. UK 67, 275-286.

Kenny A.J., Cato I., Desprez M., Fader G., Schüttenhelm R.T.E., Side J., 2003, An overview of seabed mapping technologies in the context of marine habitat classification. ICES J. Mar. Sci. 60, 411418.

Kergariou G. de, Latrouite D., Claude S., Perrodou D., 1979, Extension de la crépidule en Manche orientale. Rapp. CIEM CM 1979/K15, 1-6.

Le Gall P., 1980, Étude expérimentale de l'association en chaîne et de son influence sur la croissance et la sexualité chez la crépidule (Crepidula fornicata). Thèse Univ. Caen.

Leppäkoski E., Gollasch S., Olenin S., 2002, Alien species in European waters. In Invasive aquatic species of Europe: distribution, impacts and management. Kluwer Academic Publishers, Dordrecht, pp. 1-6.

McMillan N.F., 1938, Early records of Crepidula fornicata in English waters. Proc. Malac. Soc. London 23, 236.

Marchand Y., Auffret J.P., Deroin J.P., 1998, Dynamique sédimentaire de la baie du Mont Saint-Michel (Ouest France) depuis 1986 à partir de données satellitales. C.R. Acad. Sci Paris 327, 155-159.

Mazurié J., Bouget J.F., 2003, Estimation du stock d'huîtres creuses Crassostrea gigas en élevage, en baie de Cancale, en octobre 2002. Rapp. int. Ifremer, La Trinité.

Montaudouin X. de, Audemard C., Labour P.J., 1999, Does the slipper limpet (Crepidula fornicata) impair oyster growth and zoobenthos diversity? A revisited hypothesis. J. Exp. Mar. Biol. Ecol. 135, 105-124.

Nehls G., Diederich S., Thieltges D.W., Strasser M., 2006, Wadden Sea mussel beds invaded by oysters and slipper limpets: competition or climate control? Helgol. Mar. Res. 60, 135-143. 
Panov V., Gollasch S., 2004, Information resources on aquatic alien species in Europe on the internet; present development and future perspectives. The Colour of Ocean Data. Int. Symp. Oceanographic Data and Information Management with special attention to biological data, Brussels, Nov. 25-27, 2002. Workshop Rep. Intergovernmental Oceanographic Commission 188, pp. 115-124.

Pechenik J., 1984, The relashionship between temperature, growth rate and duration of phytoplankton life for larvae of the gastropod Crepidula fornicata (L). J. Exp. Mar. Biol. Ecol. 74, 241-257.

Pechenik J., Blanchard M., Rotjan R., 2004, Susceptibility of larval Crepidula fornicata to predation by suspension feeding adults. J. Exp. Mar. Biol. Ecol. 306, 75-94.

Quiniou F., Blanchard M., 1987, Etat de la prolifération de la crépidule (Crepidula fornicata) dans le secteur de Granville. Haliotis $16,513-526$.

Reise K., Gollasch S., Wolff W.J., 1999, Introduced marine species of the North Sea coasts. Helgol. Meeresunters. 52, 219-234.

Reise K., Olenin S., Thielges D.W., 2006, Are aliens threatening European aquatic coastal ecosystems? Helgol. Mar. Res. 60, 7783.

Richard J., Huet M., Thouzeau G., Paulet Y.M., 2006, Reproduction of the invasive slipper-limpet Crepidula fornicata in the bay of Brest (France). Mar. Biol. 149, 789-801.

Riera P., 2007, Trophic subsidies of Crassostrea gigas, Mytilus edulis and Crepidula fornicata in the bay of Mont Saint-Michel (France); a $\delta^{13} \mathrm{C}$ and $\delta^{15} \mathrm{~N}$ investigation. Estuar. Coast. Shelf Sci. $72,33-41$.
Sauriau P.G., Pichoki-Seyfreid C., Walker P., Montaudouin X. de, Palud C., Héral M., 2002, Crepidula fornicata (mollusque gastéropode) en baie de Marennes-Oléron : cartographie des fonds par sonar à balayage latéral et estimation du stock. Oceanol. Acta 21, 353-362.

Thieltges D.W., Strasser M., Van Beusekom J.E.E., Reise K., 2004, Too cold to prosper; winter mortality prevents population increase of the introduced American slipper limpet Crepidula fornicata in Northern Europe. J. Exp. Mar. Biol. Ecol. 11, 375-391.

Utting S.D., Spencer B.E., 1992, Introductions of marine bivalve mollusks into the United Kingdom for commercial culture, case histories. ICES Mar. Sci. Symp. 194, 84-91.

Vaslet D., Larsonneur C., Auffret J.P., 1978, Carte des sédiments superficiels de la Manche au 1/500 000 et notice. BRGM, Orléans.

Viard F., Ellien C., Dupont L., 2006, Dispersal ability and invasion success of Crepidula fornicata in a single gulf; insights from genetic markers and larval dispersal model. Helgol. Mar. Res. 60, 144-152.

Walne P.R., 1951, The biology and distribution of the slipper limpet Crepidula fornicata in Essex rivers. Fish. Invest. Ser. 2, 20, 1-50.

Wildish D.J., Fader G.B.J., Lawton P., Mac Donald A.J., 1998, The acoustic detection and characteristics of sublittoral bivalve reefs in the bay of Fundy. Cont. Shelf Res. 18, 105-113.

Wolff W.J., Reise K., 2002, Oyster imports as a vector for the introduction of alien species into northern and western Europe coastal waters. In: Invasive aquatic species of Europe: distribution, impacts and management. Kluwer Academic Publishers, Dordrecht, pp. 193-205. 